\title{
Human impact on fluvial systems in Europe with special regard to today's river restorations
}

\author{
Anna-Lisa Maaß ${ }^{1 *} \mathbb{D}$, Holger Schüttrumpf ${ }^{1}$ and Frank Lehmkuhl²
}

\begin{abstract}
Climate, geology, geomorphology, soil, vegetation, geomorphology, hydrology, and human impact affect river-floodplain systems, especially their sediment load and channel morphology. Since the beginning of the Holocene, human activity is present at different scales from the catchment to the channel and has had an increasing influence on fluvial systems. Today, many river-floodplain systems are transformed in course of river restorations to "natural" hydrodynamic and morphodynamic conditions without human impacts. Information is missing for the historical or rather "natural" as well as for the present-day situation. Changes of the "natural" sediment fluxes in the last centuries result in changes of the fluvial morphology. The success of river restorations depends on substantial knowledge about historical as well as present-day fluvial morphodynamics. Therefore, it is necessary to analyze the consequences of historical impacts on fluvial morphodynamics and additionally the future implications of present-day human impacts in course of river restorations. The objective of this review is to summarize catchment impacts and river channel impacts since the beginning of the Holocene in Europe on the fluvial morphodynamics, to critically investigate their consequences on the environment, and to evaluate the possibility to return to a "natural" morphological river state.
\end{abstract}

Keywords: Human impacts, Fluvial morphodynamics, Natural morphology, River restoration

\section{Background}

River-floodplain systems all over the world are strongly impacted by natural and anthropogenic activities [19, 42]. A superposition of short- and especially long-lasting impact factors characterizes and drives today's riverfloodplain systems, whereas it is difficult to distinguish between natural and anthropogenic causes [2]. Human impact continuously increased since the beginning of the Holocene $[5,41,43,95]$ and can therefore be seen as an essential factor for changes of fluvial systems [9, 23, $38]$. Floodplains contain the sedimentary history $[19,65]$ and therefore information about river response to external impacts. In Central Europe floodplain deposits are mainly related to periods of intensified human activities,

*Correspondence: anna-lisa.maass@rwth-aachen.de

${ }^{1}$ Institute of Hydraulic Engineering and Water Resources Management, RWTH Aachen University, Mies-van-der-Rohe-Straße 17, 52056 Aachen, Germany

Full list of author information is available at the end of the article whereas alluvial deposits are mainly related to climatic changes $[69,95]$.

From a global perspective, Best [4] summarized the anthropogenic stresses on the world's big rivers. Goudie [35], Goudie and Viles [36] and Nilsson et al. [60] took the same global perspective into account and focused on the geomorphology of "World's Large River Systems" in the Anthropocene [60].

With a focus on Central Europe, anthropogenic factors include catchment impacts like land use change including agriculture, deforestation, reforestation, and urbanization, which affect runoff and sediment yield, as well as river channel impacts like river regulations, dams, reservoirs, water abstraction, gravel mining, canalization, dredging, embankment or riprap, which directly modify the channel and the floodplains [63]; [43, 57, 61, $74-76,92]$. Figure 1 shows a schematic diagram of different human impact factors in Central Europe on riverfloodplain systems since the beginning of the Holocene with different phases and intensities of the following 


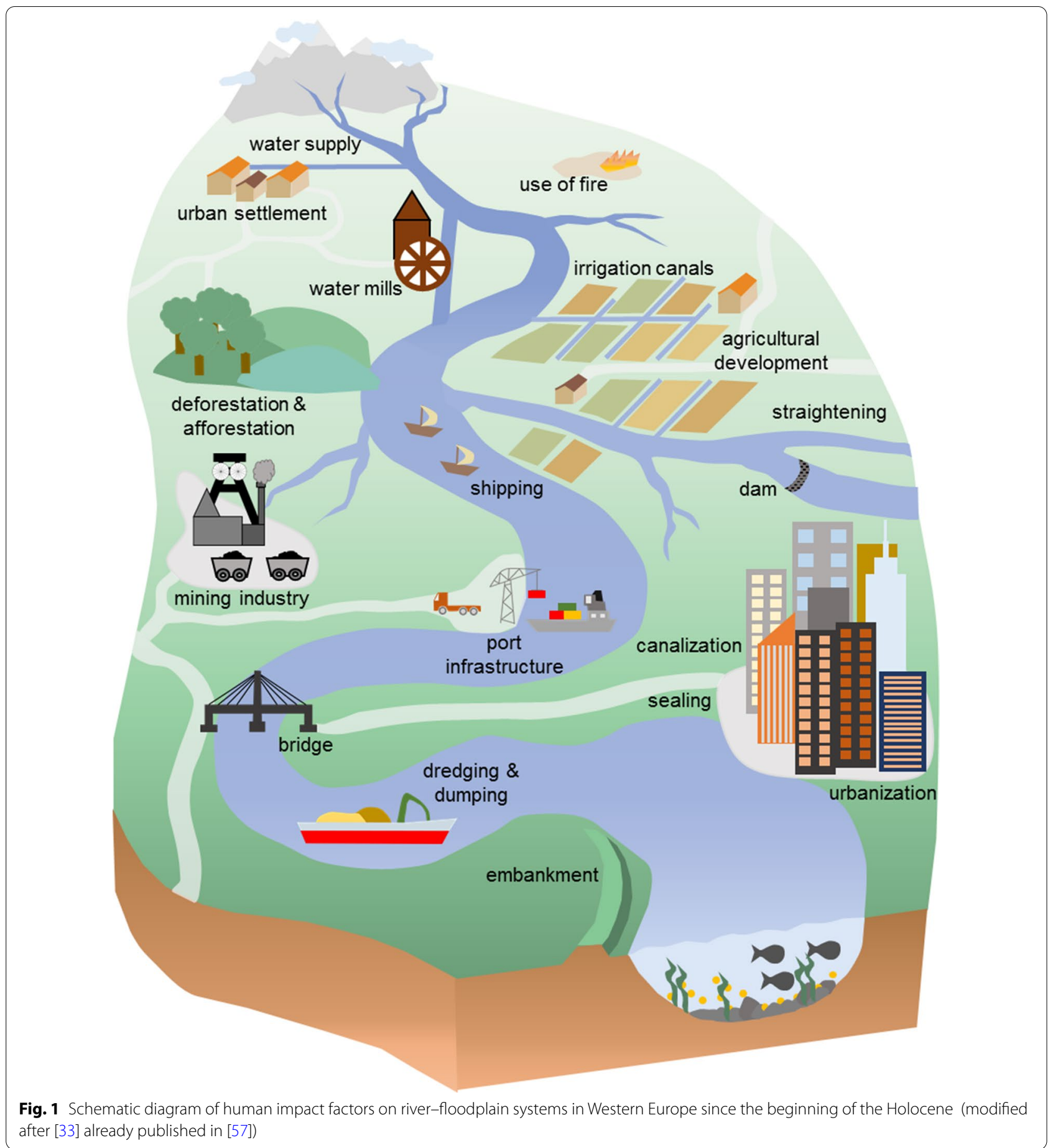

impacts. Enhanced colluviation, floodplain accumulation, and river delta progradation was highly diachronous and started in different societies and ecozones at different times [51]. They divided the agriculture development in four main phases: (1) the beginning of agriculture in the Mediterranean ecozone since Neolithic revolution times and enhanced land use during the metal ages until the antique; (2) the enhanced impact of agriculture and soil erosion in medieval time especially in Europe; (3) the first acceleration in the seventeenth to twentieth century, and (4) the Great Acceleration after WW II. Today, consequences of former anthropogenic impacts are counteracted by river restorations to enable a "natural" development of a river towards pre-defined guiding 
principles. But, what about the fact that today's river restorations are still human impacts? What did we learn from the past for the future?

The objective of this review is to summarize catchment impacts and river channel impacts since the beginning of the Holocene, to critically investigate their consequences on the environment, and to evaluate the possibility to return to a "natural" morphological river state.

In the following, catchment impacts, and river channel impacts are presented. Then, the consequences of different human impact factors are discussed. At the end, it is critically evaluated if it is possible or not to return to a "natural" morphological state as this is for example one major aim of river renaturation in the frame of European Water Framework Directive. The conclusions are given in the last section.

\section{Catchment impacts}

Catchment impacts on fluvial hydro- and morphodynamics are characterized by natural impacts like climate and tectonic activity as boundary conditions or soil and vegetation cover as controlling factors as well as by anthropogenic impacts like land use changes or urbanization (see also [51]). Since the Neolithic (in Central Europe mainly 5500 years ago, [94]), humans settled down, established agriculture and forest clearance began locally. River floodplain systems were no longer not only impacted by climate, vegetation and geology, but also by social, political, economic and technical impact factors. Anthropogenic activity affected soils and resulted in different erosion and deposition processes. Taking a temporal offset under consideration, anthropogenically induced soil erosion led to increased sediment inputs in river systems
$[40,41,50,54,58,66]$ and consequently to an increased formation of colluvial deposits [7, 21].

Land use such as forestry, agriculture and pasture increase soil erosion, sediment yield, water runoff and peak discharges as a result of reduced infiltration rates [43]. Heavy machinery or trampling by livestock produce soil compaction and increase overland flows [43].

Farming, mining and use of fire resulted in substantial forest clearances. Periodically deforested slopes with thick weathering covers were identified as the source areas for a fast sediment transfer towards the channels, which occurred during intense precipitation events [45].

Ongoing urbanization reduces soil permeability and increases peak flood magnitude, while sediment delivery is increased during construction of urban areas and is decreased after the construction phase [43].

In Fig. 2, the effect of different catchment impacts on the input of soils and sediments to the river-floodplain system is schematized.

Fine sediments play a major role in the distribution of contaminants during flood events. Contaminants absorbed on fine sediment can be deposited on the river bed or on the floodplains and might be remobilized by subsequent flood events. Floodplains act as a trap for fluvial fine, cohesive, potentially contaminated sediment. Therefore, changes in fine sediment fluxes are of importance especially in (old) industrial regions [32]. Figure 3 shows the development of land use changes and soil erosion in Central Europe since the occurrence of widespread deforestations. Phases of stabilization and destabilization in soil erosion alternated in the last centuries due to different land use changes [8].

The conceptual graph of Fig. 3 on the development of soil erosion, which originates from Bork [8], involves an

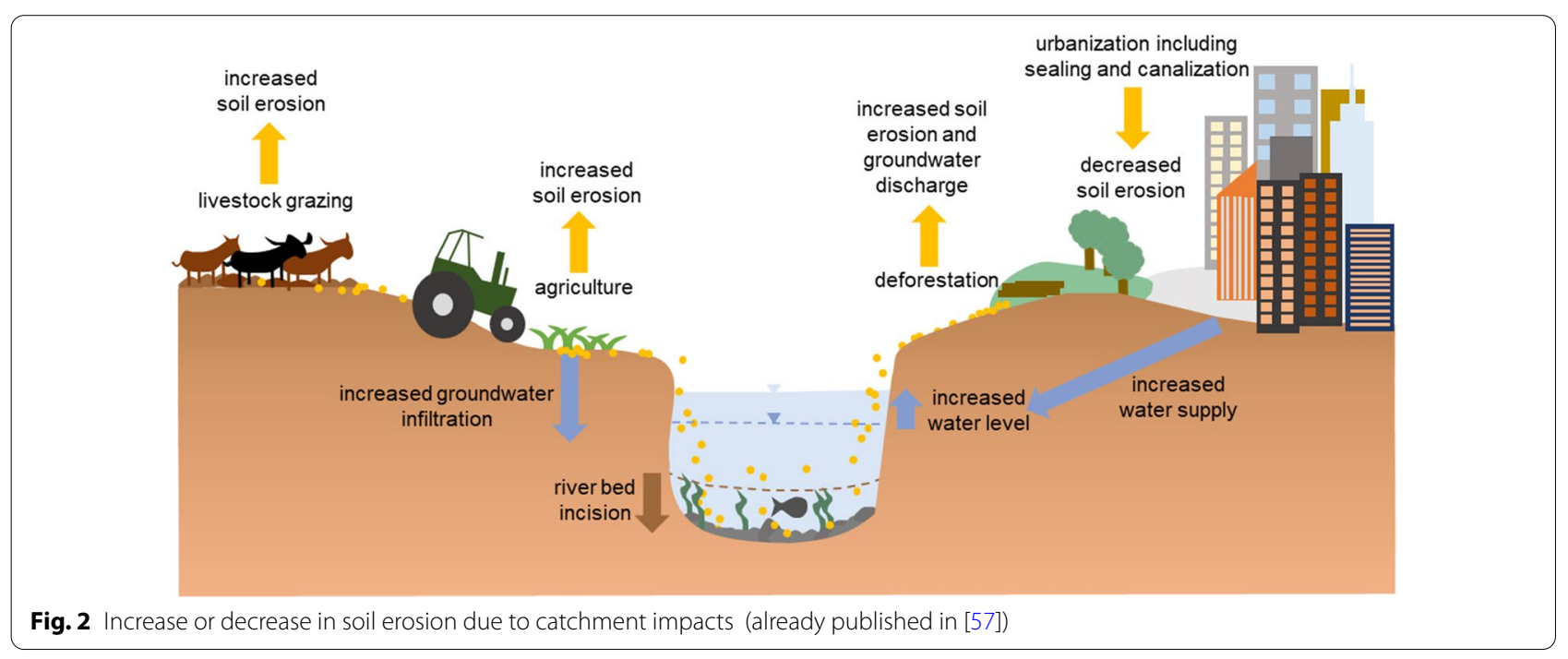




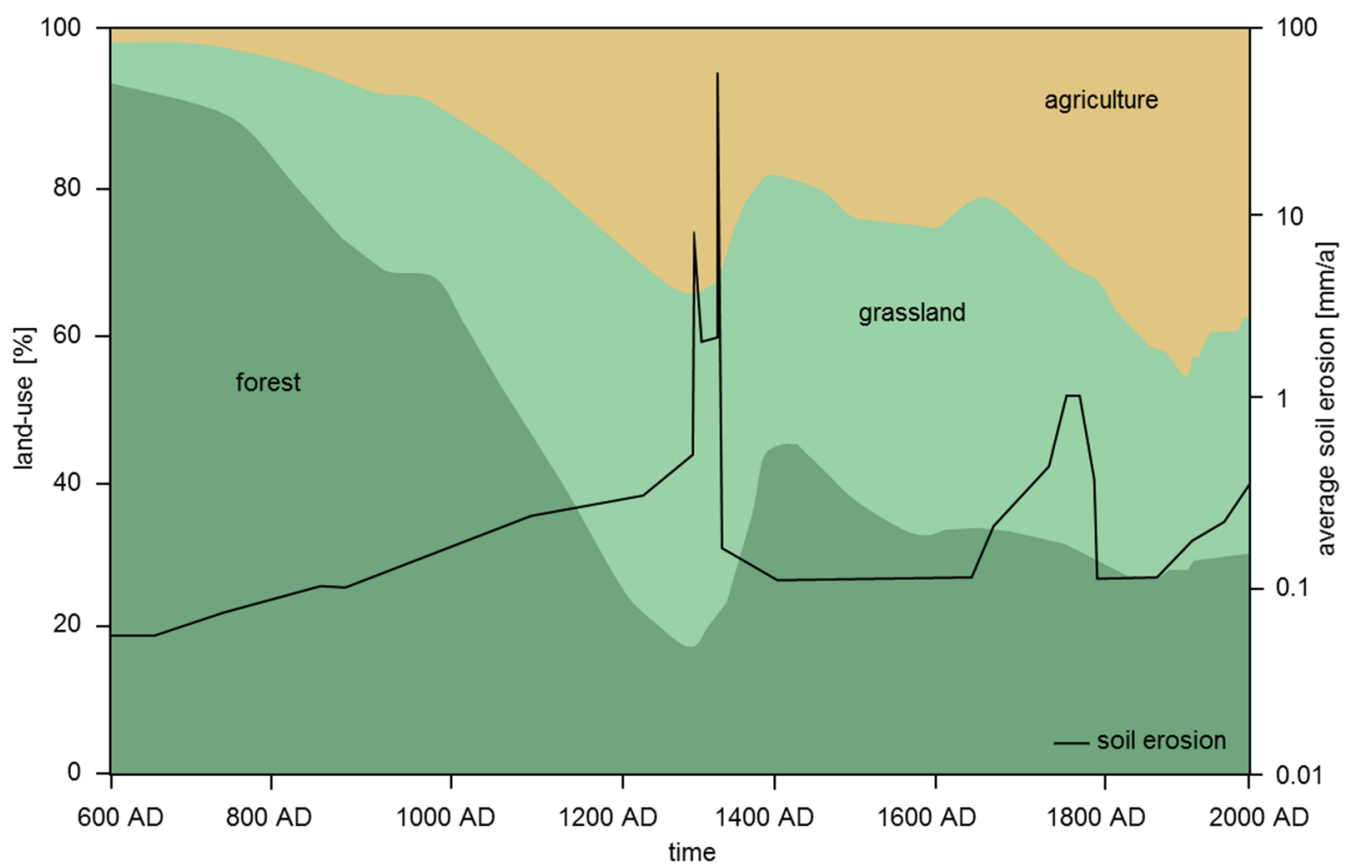

Fig. 3 Development of land use and soil erosion in Central Europe (modified after [8] already published in [57])

increase in sediment loads due to land use changes for Central Europe including deforestations, agriculture, farming and pasture. The graph also includes climate impacts and especially the role of extreme rainstorms [8]. These increasing and decreasing effects overlap, so that it is uncertain, which factor is the dominant one and if today's sediment loads are above, below or on the same level as the initial sediment loads (see Fig. 3). There is often a lack of historical sediment data or long-term sediment records, so that the quantification of historical sediment loads is one of the most important challenges [85].

In the last few decades, many case studies investigated past soil erosion and fluvial deposits at different time and spatial scales (e.g., [7, 19, 21, 22, 41, 45, 49, 61, 95]). Most of these studies focused on the dynamics of fluvial systems in response to soil erosion, land use impact and climate changes and considered these factors as the predominant factors for increased sediment transport and deposition.

For example, Dotterweich [19] reviewed past soil erosion in Central Europe and its impact on the colluvial system and the smallest floodplains with respect to climatic and land cover variations. Their results indicated that sediment fluxes in small colluvial catchments are very sensitive to local land cover changes, while sediments in small alluvial catchment show more regional trends.

Klimek and Latocha [45] analyzed the effects of deforestation or changes in plant communities, forest roads construction, forest fires and introduction of agriculture on small mid-mountain catchments. They concluded that a strong human impact on the slope-valley system in the mid-mountain part of the Eastern Sudetes affected changes in the dynamics and morphology of small rivers to a much higher extent than the climate variations, especially during the Little Ice Age.

Many studies focused on the sedimentological and morphological history of the Rhine River. In the Rhine drainage basin, agricultural activities began approximately 5500 years ago [94]. The loess landscape of northern Switzerland, Southern Germany, the Lower Rhine Embayment, and France were especially favorable for settlement, due to their fertile soils and relatively mild climate [53]. By Medieval Times the whole Rhine catchment had been settled, with only a few exceptions in isolated mountain environments [49]. In the Rhine catchment, the transition from the Pleistocene to the Holocene caused a change in the fluvial regime and subsequent human impacts are reflected in phases of colluvial as well as of alluvial sedimentation, although episodes of sediment generation are broadly consistent with periods of greater human activity [49]. Hoffmann et al. [41] stated that the progressive incision of the Rhine River in the Upper and Lower Rhine Valley during the Holocene decreased the floodplain area, resulting in a smaller accumulation space and therefore possible higher sedimentation rates. But, this process is counteracted by a reduced sediment trapping efficiency of the floodplains. The fact that floodplain sedimentation rates increase in the aggrading Rhine delta 
clearly indicates increasing sediment input into the River Rhine during the last 3000 years $[41,59]$.

It is not possible to understand Central European landscapes without knowledge about historical land use practices, because the onset of agriculture with the domestication of animals and the cultivation of plants caused a strong impact of man on the environment [66]. Klimek and Latocha [45] and Dotterweich [19] concluded that changes in land use have been proved to be the most important factors influencing the type, intensity and distribution of slope and channel processes in mountain areas and that these human-induced changes superimposed even the climatic factors. Although the general interaction of changes in river geoecology in relation to the growing impact of humans during the Holocene is extensively analyzed, many uncertainties on the exact timing and nature of this relation still exist [9]. However, there is often a synchronicity between the natural and anthropogenic variations such as land use and climate, so that the main driving forces are difficult to differentiate [61].

\section{River channel impacts}

River channel impacts on fluvial hydro- and morphodynamics are, e.g., flow regulation by construction of dams, flow diversion for irrigation or flood control, channel engineering by construction of levees, bank stabilization, canalization, embankment or channelization or feedback mechanisms like damaging of dams and widening of canal heads by natural peak flows or increased in-channel aggradation due to water extraction. These activities have affected and still affect "natural" fluvial morphodynamics like channel belt aggradation, channel incision, crevasse channel development, crevasse splay progradation as well as vertical adjustments, changes in channel width and pattern $[38,74]$.

Further technological development and growth of population led to greater river modifications and geometrical changes of river-floodplain systems. Already in the Iron Age (in Central Europe approximately $800 \mathrm{BC}$ to $50 \mathrm{BC}$ ), river channel impacts such as water mills and dams were constructed, or rivers were straightened, which directly affected fluvial morphodynamics [80].

In the Medieval Times (fifth to fifteenth century), the formation of mills, mining activities and an increase in settlement led to increased and widespread soil erosion and therefore to an increased sediment input and morphological changes [80] as well as another period of increased colluvial deposits [7, 52].

Since the Industrial Revolution ( $\sim 200$ years ago), rivers were embanked, narrowed and extensively straightened, which extensively changed firstly the hydrodynamic and secondly the morphodynamic behavior of a river.
Additionally, humans settled down closer to rivers. Urbanization required greater flood protection measures, whereas the ongoing industrialization led to an increased input of contaminants into river-floodplain systems [70]. The Industrial Revolution and the accompanying increasing urbanization, the increasing water demand for industry and sewage plant result also in a greater input of new and different contaminants in river systems.

During the nineteenth century intended morphodynamic changes were initiated by engineering work (see Fig. 3) to permit the passage of ships, hydro-electric power plants, and flood protection [49]. One of the most prominent changes was the straightening of the course of the Rhine River in the Upper Rhine Valley by Johann Gottfried Tulla (engineer, 1770 AD-1828 AD) in the early nineteenth century, which came along with building and draining of wetlands and straightening of smaller river parts and tributaries and began to drastically change the fluvial regime of the Rhine River [49]. Spatially, the Rhine correction came also along with surface sealing due to construction of roads, which overall resulted in an increased land use closer to rivers.

Additionally, dredging and gravel mining produce large impacts because these techniques reduce the solid discharge of rivers and destroy geomorphological landforms [43].

Sometimes, rivers have also been completely fixed and channelized by continuous structures [74]. Streambank protection structures such as groynes and levees constrain the river to maintain a narrower channel, reducing bank erosion and giving opportunity for agricultural uses [74], which shows the close link between river channel and catchment impacts.

Besides channelization and straightening of rivers, a major impact of human activity on river channel form is caused by dams (see Fig. 4). The construction of dams affects the sediment transport in river systems since several centuries. Dams are constructed for flood protection, for irrigation or drinking water facilities, to provide navigation channels with water and to guarantee a sufficient water level for navigation [30, 48, 76]. The construction of dams accompanies with a limited migration of waterbound organisms like fishes, macrozoobenthic and macrophytes as well as an interrupted transport of sediment [30]. Upstream of dams, water is impounded, flow velocity is reduced, and sediment is deposited on the river bed [10]. The deposition leads to a decreased sediment transport in downstream direction in comparison to the initial situation without the dam.

Dams with diversion channels can also change the base level up- and downstream of the dam location. Upstream, water is impounded, and flow velocity is decelerated, which led to deposition of sediment and a decreased 


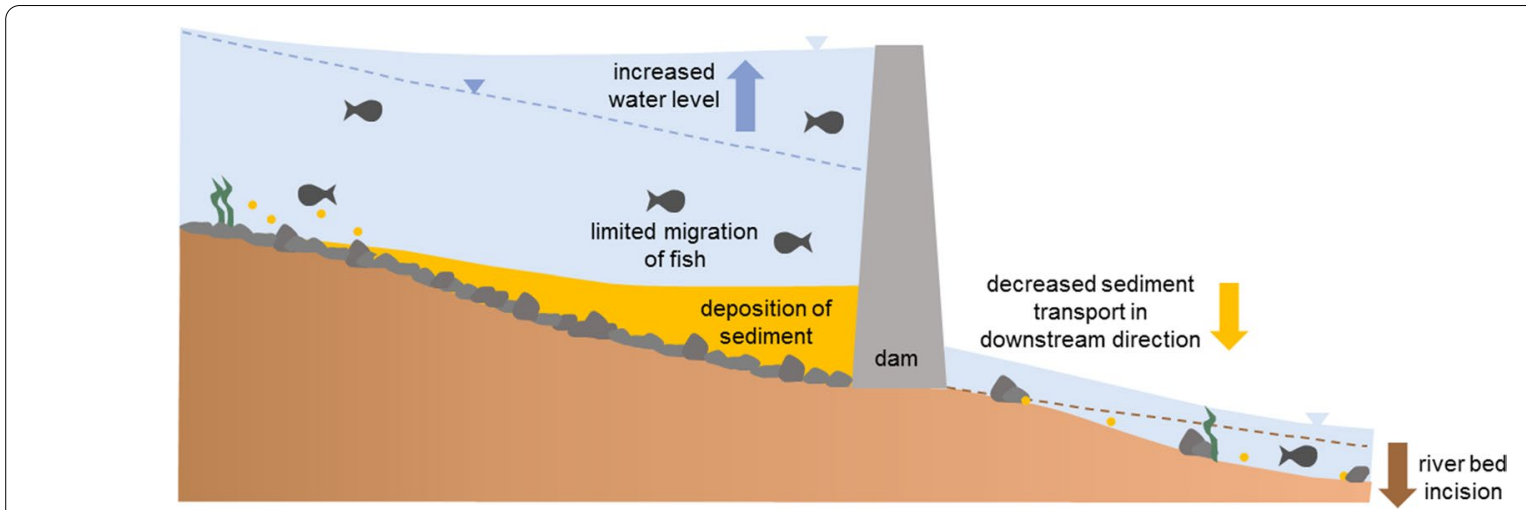

Fig. 4 Consequences of dam construction on fluvial morphodynamics as an example of river channel impacts

channel slope, whereas the decreased water discharge and sediment load downstream of dams result in an increased slope, river bed incision, channel narrowing, encroachment of plants and loss of spawning gravels for salmon and trout, when smaller gravels are transported without being replaced by upstream ones [47]. Once the diverted water flows back into the main channel, water discharge is recovered but sediment load is not, which produces vertical erosion processes and changes in sediment load [43].

Following Frings and Maaß [30], it is necessary to distinguish between the sediment fluxes of coarse and fine sediments especially focusing on the impact of reservoirs. Dams typically have trapping efficiencies of $100 \%$ for gravel. Sand can pass many smaller dams on steep streams with turbulent flows, but is typically not able to pass large reservoirs. Silt and clay are always transported as suspended-load or as wash-load and can pass through the river network and small dams without significant storage capacities mostly without being deposited [48].

\section{Consequences of human impacts in Central Europe}

Focusing again on large dams, positive consequences are the economically least-cost source of electric power, and that hydropower is a renewable electricity source [1], whereas negative consequences of the construction of large dams accompanies with the destruction of a unique biodiversity.

Generally, one major consequence of dams is the drastically decreased sediment transport to river deltas (e.g., Nile Delta, Egypt in [72] or Yangtze Delta in [15] and coastal zones $[47,76,83,84])$. The deposition of sediments upstream of dams can result in increased water levels and consequently in a greater risk for flooding or in decreased reservoir storage capacities and therefore in decreased drinking or irrigation water supplies and decreased energy yields from waterpower [30, 48].
Simultaneous, channel incision downstream of dams can result in loss of riparian land and infrastructure due to decreasing ground water levels [48, 92]. Erosion of sediment downstream of dams leads to negative consequences like bank erosion and a (unintended) change of adjacent landscape, scour holes around bridge piers, an irregular surface area of the river bed and consequently barriers for ships [34, 47, 68]. Given some examples outside of Europe, for example, at the Kaoping River (Taiwan), head cutting of over $7 \mathrm{~m}$ from an in-stream gravel mine endangers the Kaoping Bridge, whose downstream margin is now protected with gabions, massive coastal concrete jacks and lengthened pipes [47]. At the San Luis Rey River (USA), in-stream gravel mining has not only reduced the supply of sediment to the coast, but mininginduced incision has exposed aqueducts, gas pipelines, and other utilities buried in the bed [47]. At the Atrak River (Iran), bank erosion led to village damages and the destruction of numerous infrastructures such as bridges, roads and buildings [92]. Further negative consequences are related to the accelerated process of decoupling floodplains from the river channel (see Maaß and Schüttrumpf [56]: $1 \mathrm{~cm} / \mathrm{a}$ of floodplain sediment deposition during the phase of active water mills against $0.1 \mathrm{~cm} / \mathrm{a}$ of floodplain deposition after water mill removal) accompanied with lowering of water and groundwater levels [22, 59]. Channel incision and channel narrowing can have negative consequences in terms of undermining of structures, loss of groundwater storage or a loss of habitat diversity [74]. A decrease in drinking and irrigation water supplies, a decline in earnings from fishery and waterpower and an increase in inundation follow sooner or later in diseases, poverty or social civil disturbance [30]. A better understanding of channel adjustments is essential for preventing their environmental, social and economic consequences, and predicting future unintended channel evolution [74]. 
Economic consequences are, e.g., related to decreasing reservoir capacities due to deposition of sediment inside the reservoir. Different sediment management strategies, which are again human impacts on fluvial morphodynamics, already exist that prolong reservoir life and benefit downstream reaches by mitigating the sediment starvation that results from sediment trapping. These strategies include, e.g., sediment bypassing and off-channel reservoir storage or upstream sediment management approaches such as catchment erosion control as well as sediment augmentation downstream of dams [48]. Until now, dams have typically been located based principally on engineering, economic, and often political consideration, and commonly on land already owned by the dam proponent or otherwise convenient for the purpose. The larger spatial and temporal context of the entire catchment and a sustainable use of the dam were often disregarded [48].

Human impacts led also to negative consequences on fluvial environments in terms of reduced floodplain biodiversity and modified flow regimes [42]. E.g., reservoirs impend the movement of organisms, change flow regimes and alter habitats and therefore substantially impact on the aquatic biodiversity [82]. Upstream of dams, flow velocities are reduced to almost zero, which leads to reduced oxygenation and dilution of pollutants and a deterioration of the water quality in comparison to the fast-flowing rivers [1]. Downstream of dams, riparian ecosystems depending on periodic natural flooding might be destroyed [1].

Ecosystem changes are also related to changes of the grain size composition of a river-floodplain system. Different plants and animals live on or in different kinds of substrate. Shifts in the river ecosystem directly affect these poorest people, often deeply threatening their health, ability to work, and spiritual well-being [1, 88]. Especially the fine sediment fraction with a median sediment diameter $D 50<2 \mathrm{~mm}$ is of importance. Deposition of silt and clay in harbor basins or irrigation channels might lead to clogging of the basins or channels and therefore to increased dredging costs and especially these fine sediments might be (chemically) contaminated [30]. The decision, if the transport of fine sediment should be promoted or limited in a river-floodplain system depends on site specific conditions and of the material (coarse or fine sediment), which should be transported [30]. Additionally, fine sediments are able to absorb contaminants, distribute them on the river bed and during flood events on the floodplains or close the interstitial space, which forms a spawning habitat for salmonids. Accumulation of contaminated sediment can cause negative consequences for the aquatic and terrestrial environment $[16,17]$.
Several studies have already mentioned the conflicting interests of river management, e.g., Hoffmann et al. [42] stated that the society has, in general, benefitted from the natural resources afforded by rivers and floodplains, but that simultaneously the river management of the last decades led to negative impacts on fluvial environments including reduced floodplain biodiversity and modified flow regimes. A successful restoration and as a consequence successful integrated water management strategy depend on a striking balance between human resource use and ecosystem protection [82]. Human impact factors in river-floodplain systems have changed and still change natural sediment fluxes resulting in deposition or erosion with widespread ecological, social and economic consequences. Assessments of economic development, ecosystem services and their contribution depend on hydrodynamic and morphodynamic changes [82]. Overall, the success of integrated water management strategies depends on striking a balance between human resource use and ecosystem protection [82].

\section{Today's river restorations are still human impacts!}

Since the last 50 years, river restorations are realized to transform river-floodplain systems in a more "natural" hydrological and morphological state, but restoration projects are again an anthropogenic impact.

River management that accounts for often-conflicting interests requires awareness and understanding of "natural" morphodynamic processes such as lateral migration [80]. Therefore, understanding historical hydrodynamic and morphodynamic river conditions, monitoring present-day processes and assessing future development are essential for today's proper river management (see also [57]).

In the twenty-first century, national (e.g., German Water Resources Law) and international (e.g., EU Water Framework Directive) laws and guidelines emphasize a natural hydrological and morphological development. The "natural" characteristics of a river-floodplain system are abstracted and formulated in a pre-defined guiding principle, which also considers irreversible anthropogenic impacts [64]. The pre-defined development goals should be realized within river restorations and are evaluated comparing the current state of a river and its guiding principle with each other. During river restorations, flooding areas are generated, flow lengths are increased, anthropogenic barriers are reduced, and a "natural" river development is initiated [31].

The motivation behind river restoration projects varies with land ownership, funding agency and cultural setting [44] and there is often the problem of presenting the public a "good and healthy" river-floodplain system [90]. For 
the public, a river is healthy if the water is clear, and the stream banks are not rapidly eroding [89].

Today, many river restorations are accompanied by the removal of transverse structures to ensure better passability for fish and/or continuous transport of sediment. But, the synergy of construction and removal of these transverse structures will always result in incision of the river bed, e.g., Buchty-Lemke and Lehmkuhl [12] analyzed the impacts of the abandonment of historical water mills (as an example of transverse structures) of the Wurm River in Western Germany. They concluded that the abandonment of the mill and removal of the weir triggered a morphological adjustment process that created terraces upstream of the mill and balanced the mill-induced knickpoint in the longitudinal profile. However, such an adjustment process can be superimposed by anthropogenic influences that control the availability of sediment and discharge conditions and channel and planform changes are different in straight, meandering and fixed river reaches. River channel human activities and the way in which the mill abandonment was conducted additionally control the fluvial morphodynamics [12]. Furthermore, effects of channel instability and river widths variations are analyzed by, e.g., Downward and Skinner [20], Chang [13] or Bishop et al. [6].

With respect to river restoration, it is important and indispensable to consider that mill abandonment (or in general the removal of transverse structures) lead to upstream incision. If the aim of such a removal is to lead to a higher connectivity between the channel and its floodplains or to result in a higher transversal morphodynamic behavior of the river, the removal might miss its aim.

In general, river incision is not intended by river managers due to its negative effects on floodplain ecology, but after the removal of a transverse structure, a river aims to re-establish is longitudinal profile before mill construction. Therefore, the "simple" removal might not always be the solution for a better passability for fish and/or continuous transport of sediment.

Considerations of removing a transverse structure should be accompanied with an analysis of the predominant sediments by, e.g., 1D to $3 \mathrm{D}$ numerical models and sensitivity analysis to analyze the future development of the river without the transverse structure. Numerical models are proven tools for predicting morphodynamic systems, e.g., the 1D morphodynamic models of Gary Parker (see http://hydrolab.illinois.edu/people/parkerg/ morphodynamics_e-book.htm) offer a procedure predicting large-scale in terms of century-time studies). In contrast, 3D numerical modeling can predict small-scale but very detailed morphodynamic changes. The numerical model investigation of rivers in Central Europe of
Török et al. [78] or Fischer-Antze et al. [25] show that numerical tools already exist for small and large spacetime scale studies, rather their reliable parameterization is questionable.

In literature, only a few controversial results of the impact of water mills (again as an example for transverse structures) on fluvial morphodynamics can be found (see e.g., [86]). E.g., Donovan et al. [18] focused their research on the mid-Atlantic region and stated that channel banks in close proximity to breached mill dams serve as hotspots of local erosion and deposition, but that not all sediment hot spots are mill dams and that not all mill dams are hotspots. Although historical mill dams and legacy sediments are widespread, they do not necessarily have uniform impacts on sediment yield [18].

From a more general point of view, the impacts of increased bank heights due to transverse structures such as water mills on the fluvial morphology are similar to those of embankments [26, 37, 93]. Due to the higher floodplains, bankfull water levels are increased in the main channel in comparison to the water levels predating mills. The increased water levels cause an increase in the shear stresses. An increase of the bed shear stress typically leads to the erosion of fine grains and coarsening of the river bed grain sizes [26]. Here, incision is also associated with problems that continue today such as in the excavation of pipelines and the construction of foundations for engineering works and in navigability issues during low flow, as well as the drying of natural vegetation on the embanked floodplains (see also [57]).

In Maaß [57], the effects of a river-mill system were analyzed using physically based equations of backwater effects and sediment mobility in combination with field measurements of the channel slope and floodplain development pre- and postdating water mills in two very similar river-floodplain systems. The morphology before water mill construction was reconstructed analyzing a gravel bed layer visible at the river bank of the Wurm River (Germany), which represents the historical pre-mill river bed [12]. Floodplain accretion was determined in the Geul River (Netherlands) using artificial lawn mats as sediment traps. The similarity of two meandering gravelbed streams with silty floodplains was used to study the effect of mills in operation and of their removal, allowing a degree of control that is usually only the case in experiments or numerical models.

The results of van Oorschot [79] and Maaß et al. [55] show that the vegetation cover affects the morphological development of a river-floodplain system to a certain extent. A monitoring program of a time period of more than one decade could not be found in the literature, which underlines the uniqueness of the field measurements at the Inde River (NRW, Germany), e.g., the 
studies of Pasquale et al. [62] and Chapuis et al. [14] were conducted over a time period of only 1 or 2 years, so that the results of the morphological development strongly depend on the discharges present during this time. Longterm monitoring programs should be performed to verify the restoration success and to filter out the local effects of natural variation such as the influence of vegetation cover ([79], see also [57]).

For example, at the Inde River, Maaß et al. [57] analyzed sediment raps, echo soundings and hillside erosion/vegetation cover due to the new Inde River were relocated and newly planned. The results of the field data collections were used to characterize the channel pattern and sedimentology, erosion and sedimentation rates, hillside erosion, sediment trapping as well as the input and transport of heavy metals [57].

These two examples show that direct field data collection for the condition assessment and the validation and parameterization of numerical models also play a key role in context of analyzing human impacts on fluvial morphodynamics.

\section{Lessons learnt for the future}

Restoration interventions are always in an area of tension between securing flood protection, re-establishing "natural" discharge conditions, considering urban management and protection of historical buildings, "natural" river development and maintenance as well as public perception and acceptance [3]. Wohl et al. [90] stated that there is a challenge for river restoration focusing on the large gap between knowledge of processes such as sediment transport and the ability to use that knowledge for prediction or measurements within river restorations (see also [57]).

In former times, changes in river-floodplain systems resulted from economic aspects. Today, especially ecological aspects and nature conservation are focused. However, the overall aim of a sustainable and "natural" river management should not focus on only one of these aspects, but should include all aspects: ecological, social, economic and morphodynamic aspects [71]. Such an encompassing approach is already defined in the EU Water Framework Directive. To achieve these goals, it is necessary to focus more on the interactions between ecology, hydro- and morphodynamics and not on each factor individually [71]. Therefore, "natural" river dynamics are often wrongly perceived and classified as humaninduced river dynamics (see also [57]).

Overall, morphodynamic active rivers are spatially and temporarily variable and do not represent one "natural" reference state. Rivers are dynamic systems that will not remain in one morphological state but will continuously change due to external effects such as varying discharges even without any human impact. Understanding the history of fluvial morphodynamics and their long-term changes is essential for restoring river-floodplain systems $[44,89]$. The sustainability of restorations is often neglected in restoration projects. Frings and Maaß [30] mentioned that it is already embedded in the EU Water Framework Directive that it is not possible to achieve a "natural" morphological state. Generally, sediment should not be seen as a disturbing factor, but should be seen as an intrinsic, inseparable part of river-floodplain systems. The success of river restorations depends on substantial knowledge about historical as well as presentday fluvial morphodynamics. Such a knowledge can be acquired, e.g., with sediment fingerprinting, sediment tracing and sediment budget analyses (for the Rhine: [27-29, 39] or for the Danube River: [87]) based on analysis of historical maps as well as theoretical, physical or numerical models (see also [57]).

Even though it is sometimes possible to restore an initial, "natural" hydrological situation, but it is (often) not possible to achieve initial, "natural" morphodynamic conditions. Human impacts of the last decades to centuries have irreversibly changed the fluvial morphodynamics. But, ending up some human impact factors, it might be possible to restrict further unintended and negative morphological changes and to transform river-floodplain systems in a state, which is of equal value as the natural morphological state $[30,46,57]$.

Lots of research already focuses on human impacts on large river-floodplain systems (macro-catchments) $[26,41,54]$. Understanding fluvial morphodynamics on river basin scales is always important to investigate not only general impact factors (like sealing of the ground, deforestation, the construction of transverse structures or restoration interventions), which influence the whole river-floodplain system, but also small-scale impact factors like mining-induced subsidence, which locally influence floodplain deposition and may lead to a hotspot of (contaminated) sediments (see also [57]).

Even though research with a local focus has increased, there is still a lack of information of the historical development of a river catchment on a regional scale [73]. Buchty-Lemke [11], Maaß [57] and Esser et al. [24] show that there is already a superposition of human impacts in river catchments classified as meso-catchments such as the ones of the Wurm, the Geul and the Inde River. This superposition results from different anthropogenic impacts present in the meso-catchment and also from impact factors affecting the tributaries (micro-catchments). A clear identification of the effects from microcatchments have not been reported so far. Therefore, a detailed analysis of the relationship of micro- to mesoto even macro-catchments should be subject of future 
research [24, 91]. Micro-catchments are suitable for long-term impact-based analyses because anthropogenic changes have direct consequences on the river-floodplain system and a higher spatial and temporal resolution of morphological investigations is possible [61,67].

Additionally, morphological changes occur mainly during flood events. Floodplain inundation is rarely seen at deeply incised rivers with high, sharp banks and decoupled floodplains and only occurs after heavy rainfall with short leading times or snowmelt. Therefore, investigations of fluvial morphodynamics should always be carried out over long time scales to capture especially these morphologically significant events (see also [57]).

Overall, the different human impact factors in a river catchment should be individually investigated on a micro- to a macro-catchment scale to include the entire range of river catchment sizes. In future, the interdisciplinary analysis of river catchment and landscape development combining field measurements and numerical modeling will increase and will need further research $([77,81]$, see also [57]).

\section{Conclusions}

This review of human impacts on fluvial morphodynamics shows the widespread interest in catchment and river channel effects of human activities at large and small rivers. Today, consequences of former anthropogenic impacts are counteracted by river restorations to enable a "natural" development of a river towards pre-defined guiding principles. Each anthropogenic impact factor has its own consequences and must be analyzed individually. Historical and future long-term effects as well as largescale processes are relatively unknown so far. Therefore, it is necessary to analyze and understand the history of a river and to assess future implications for river restorations in order to guarantee a safe and sustainable river development. An improved understanding of effective morphodynamic processes is indispensable for river restorations and river management strategies. Achieving a "natural" morphological river state means taking the dynamic behavior of a river-floodplain system into account.

Overall, this literature review shows how different human impact factors affect sediment transport processes and fluvial morphodynamics. Sediment transport and especially morphodynamic processes are often long-lasting processes. Theoretical analyses, numerical modeling studies, continuous or repetitive field measurements over several years are useful tools to investigate these processes. All these tools require several assumptions and simplifications, which are indispensable in order to analyze time scales of decades to even centuries. It is important to evaluate and discuss these assumptions focusing on an encompassing picture of river-floodplain systems. These systems are always (morpho-)dynamic and react to all natural and anthropogenic impact factors present inside the system. Understanding the system means understanding its history as well as its present conditions and investigating its future implications (see also [57]).

\section{Acknowledgements \\ Thanks are due to M. Buchty-Lemke, V. Esser, R. M. Frings, L. Hagemann, T. Schruff and J. Schwarzbauer.}

\section{Authors' contributions \\ ALM wrote the first draft of the manuscript. All authors contributed on specific aspects of the manuscript. This manuscript is in parts identical to a dissertation already published at the RWTH Aachen University by the same corresponding} author [57]. All authors read and approved the final manuscript.

\section{Funding}

Open Access funding enabled and organized by Projekt DEAL. This work is funded by the Deutsche Forschungsgemeinschaft (DFG) - under Project number 418362535 and Project number 274891834.

\section{Availability of data and materials}

The cross-sectional profiles of the Wurm River were generously provided by Bezirksregierung Köln, Dezernat 54, Wasserwirtschaft and are not freely accessible due to a user agreement. The discharge and water level data sets were kindly provided by Landesamt für Natur, Umwelt und Verbraucher-schutz Nordrhein-Westfalen (LANUV). For the Digital Elevation Model (DEM) see: Land NRW (2017). Datenlizenz Deutschland_Digitales Geländemodell Gitterweite 1 m-Version 2.0 (https://www.govdata.de/dl-de/by-2-0). For the discharges and water levels measured in the Wurm River see: LANUV NRW (2018). Datenlizenz Deutschland-Wasserstände und Abflüsse im Einzugs-gebiet der Wurm in 5 min Abständen-Version 2.0 (https://www.govdata.de/dl-de/by-2-0). The raw data of the turbidity and SSC measurements are uploaded in a data repository (https://doi.org/10.6084/m9.figshare.9784328).

\section{Declarations}

Ethics approval and consent to participate Not applicable.

\section{Consent for publication}

Not applicable.

\section{Competing interests}

The authors declare that they have no competing interests.

\section{Author details}

${ }^{1}$ Institute of Hydraulic Engineering and Water Resources Management, RWTH Aachen University, Mies-van-der-Rohe-Straße 17, 52056 Aachen, Germany.

${ }^{2}$ Department of Geography, RWTH Aachen University, Wüllnerstr. 5b,

52056 Aachen, Germany.

Received: 20 April 2021 Accepted: 3 October 2021

Published online: 16 October 2021

References

1. Basson GR (2005) Hydropower dams and fluvial morphological impacts - an African perspective. In: UN symposium on hydropower and sustainable development, Beijing, China, 1-17

2. Bebermeier W, Hoelzmann P, Meyer M, Schimpf S, Schütt B (2018) Late glacial to Late Holocene landscape history derived from floodplain sediments in context to prehistoric settlement sites of the southern foreland of the Harz Mountains, Germany. Quat Int 463:74-90. https:// doi.org/10.1016/j.quaint.2016.08.026 
3. Berends KD, Straatsma MW, Warmink JJ, Hulscher SJMH (2018) Uncertainty quantification of flood mitigation predictions and implications for decision making. Nat Hazards Earth Syst Sci Discuss. https://doi.org/ 10.5194/nhess-2018-325

4. Best J (2019) Anthropogenic stresses on the world's big rivers. Nat Geosci 12:7-12. https://doi.org/10.1038/s41561-018-0262-x

5. Birks HH, Gelorini V, Robinson E, Hoek WZ (2015) Impacts of palaeoclimate change 60 000-8000 years ago on humans and their environments in Europe: integrating palaeoenvironmental and archaeological data. Quat Int 378:4-13. https://doi.org/10.1016/j.quaint.2014.02.022

6. Bishop P, Muñoz-Salinas E, MacKenzie AB, Pulford I, McKibbin J (2011) The character, volume and implications of sediment impounded in mill dams in Scotland: the case of the Baldernock Mill dam in East Dunbartonshire. Earth Environ Sci Trans R Soc Edinb 101:97-110. https://doi. org/10.1017/S1755691010009205

7. Bork H, Bork H, Dalchow C, Faust B, Priorr H, Schatz T (1998) Landschaftsentwicklung in Mitteleuropa - Wirkungen des Menschen auf Landschaften. Gotha, Stuttgart

8. Bork H (2006) Landschaften der Erde unter dem Einfluss des Menschen. Primus-Verlag, Darmstadt

9. Broothaerts N, Verstraeten G, Notebaert B, Assendelft R, Kasse C, Bohncke S, Vandenberghe J (2013) Sensitivity of floodplain geoecology to human impact: a Holocene perspective for the headwaters of the Dijle catchment, central Belgium. Holocene 23:1403-1414. https://doi. org/10.1177/0959683613489583

10. Brune GM (1953) Trap efficiency of reservoirs. Trans AGU 34:407. https://doi.org/10.1029/TR034i003p00407

11. Buchty-Lemke M (2018) Untersuchungen zu anthropogenen Einflüssen auf die fluviale Morphodynamik und die Verteilung erhöhter Spurenelementgehalte in kleinen Flusseinzugsgebieten: das Beispiel der Wurm, Flussgebietseinheit Maas, Dissertation. https://doi.org/10.18154/ RWTH-2018-230081

12. Buchty-Lemke M, Lehmkuhl F (2018) Impact of abandoned water mills on Central European foothills to lowland rivers: a reach scale example from the Wurm River, Germany. Geogr Ann Ser B 10:1-19. https://doi. org/10.1080/04353676.2018.1425621

13. Chang HH (2008) Case study of fluvial modeling of river responses to dam removal. J Hydraul Eng 134:295-302. https://doi.org/10.1061/ (ASCE)0733-9429(2008)134:3(295)

14. Chapuis M, Bevan V, Macvicar B, Roy A (2015) Sediment transport and morphodynamics in an urbanized river: the effect of restoration of sediment fluxes. In: Schleiss AJ, De Cesare G, Franca MJ (eds) River flow 2014. CRC Press, London

15. Chen $X$, Yan Y, Fu R, Dou X (2008) Sediment transport from the Yangtze River, China, into the sea over the Post-Three Gorge Dam Period: a discussion. Quat Int 186(1):55-64. https://doi.org/10.1016/j.quaint.2007. 10.003

16. Cofalla C, Hudjetz S, Roger S, Brinkmann M, Frings R, Wölz J, Schmidt B, Schäffer A, Kammann U, Hecker M, Hollert H, Schüttrumpf H (2012) A combined hydraulic and toxicological approach to assess resuspended sediments during simulated flood events— part II: an interdisciplinary experimental methodology. J Soils Sediments 12:429-442. https://doi.org/10.1007/s11368-012-0476-2

17. Crawford SE, Cofalla CBN, Aumeier B, Brinkmann M, Classen E, Esser V, Ganal C, Kaip E, Häussling R, Lehmkuhl F, Letmathe P, Müller A-K, Rabinovitch I, Reicherter K, Schwarzbauer J, Schmitt M, Stauch G, Wessling M, Yüce S, Hecker M, Kidd KA, Altenburger R, Brack W, Schüttrumpf H, Hollert H (2017) Project house water: a novel interdisciplinary framework to assess the environmental and socioeconomic consequences of flood-related impacts. Environ Sci Eur 29:23. https://doi.org/10.1186/ s12302-017-0121-1

18. Donovan M, Miller A, Baker M (2016) Reassessing the role of milldams in Piedmont floodplain development and remobilization. Geomorphology 268:133-145. https://doi.org/10.1016/j.geomorph.2016.06.007

19. Dotterweich M (2008) The history of soil erosion and fluvial deposits in small catchments of central Europe: deciphering the long-term interaction between humans and the environment-a review. Geomorphology 101:192-208. https://doi.org/10.1016/j.geomorph.2008.05.023

20. Downward S, Skinner K (2005) Working rivers: the geomorphological legacy of English freshwater mills. Area 37:138-147. https://doi.org/10. $1111 / j .1475-4762.2005 .00616 . x$
21. Dreibrodt S, Lubos C, Terhorst B, Damm B, Bork H-R (2010) Historical soil erosion by water in Germany: scales and archives, chronology, research perspectives. Quat Int 222:80-95. https://doi.org/10.1016/j.quaint.2009. 06.014

22. Erkens G, Dambeck R, Volleberg KP, Bouman MTIJ, Bos JAA, Cohen KM, Wallinga J, Hoek WZ (2009) Fluvial terrace formation in the northern Upper Rhine Graben during the last 20000 years as a result of allogenic controls and autogenic evolution. Geomorphology 103:476-495. https:// doi.org/10.1016/j.geomorph.2008.07.021

23. Erkens G, Hoffmann T, Gerlach R, Klostermann J (2011) Complex fluvial response to Late glacial and Holocene allogenic forcing in the Lower Rhine Valley (Germany). Quat Sci Rev 30:611-627. https://doi.org/10. 1016/j.quascirev.2010.11.019

24. Esser V, Buchty-Lemke M, Schulte P, Podzun LS, Lehmkuhl F (2020) Signatures of recent pollution profiles in comparable central European rivers: Examples from the international River Basin District Meuse. CATENA 193:104646. https://doi.org/10.1016/j.catena.2020.104646

25. Fischer-Antze T, Olsen NRB, Gutknecht D (2008) Three-dimensional CFD modeling of morphological bed changes in the Danube River. Water Resour Res 44(9):W09422. https://doi.org/10.1029/2007WR006402

26. Frings RM, Berbee BM, Erkens G, Kleinhans MG, Gouw MJP (2009) Humaninduced changes in bed shear stress and bed grain size in the River Waal (The Netherlands) during the past 900 years. Earth Surf Process Landf 34:503-514. https://doi.org/10.1002/esp.1746

27. Frings RM, Döring R, Beckhausen C, Schüttrumpf H, Vollmer S (2014) Fluvial sediment budget of a modern, restrained river: the lower reach of the Rhine in Germany. CATENA 122:91-102. https://doi.org/10.1016/j.catena. 2014.06.007

28. Frings RM, Gehres N, Promny M, Middelkoop H, Schüttrumpf H, Vollmer S (2014) Today's sediment budget of the Rhine River channel, focusing on the Upper Rhine Graben and Rhenish Massif. Geomorphology 204:573-587. https://doi.org/10.1016/j.geomorph.2013.08.035

29. Frings RM, Ten Brinke WBM (2017) Ten reasons to set up sediment budgets for river management. Int J River Basin Manage 16:35-40. https://doi. org/10.1080/15715124.2017.1345916

30. Frings RM, Maaß A-L (2018) Sedimentkontinuität als Leitprinzip des Flussgebietsmanagements - Sind wir auf dem richtigen Weg? Hydrol Wasserbewirtsch. https://doi.org/10.5675/HyWa_2018,4_3

31. Gerken B, Schwarz U, Priebe C (1988) Auen:Verborgene Lebensadern der Natur, 1st edn. Rombach, Freiburg im Breisgau

32. Germershausen $L$ (2013) Auswirkungen der Landnutzung auf den Schwermetall- und Nährstoffhaushalt in der Innersteaue zwischen Langelsheim und Ruthe. Hildesheimer Geographische Studien, vol 1. Inst. f. Geographie, Hildesheim

33. Gibling MR (2018) River systems and the anthropocene: a late pleistocene and holocene timeline for human influence. Quaternary 1:21. https://doi. org/10.3390/quat1030021

34. Gölz E (1994) Bed degradation —nature, causes, countermeasures. Water Sci Technol 29:325-333. https://doi.org/10.2166/wst.1994.0130

35. Goudie A (2019) Human impact on the natural environment: past, present and future, 8th edn. Wiley-Blackwell, Hoboken, p 472. ISBN 978-1-119-40355-5

36. Goudie A, Viles H (2016) Geomorphology in the anthropocene. Cambridge University Press, Cambridge. https://doi.org/10.1017/CBO9781316 498910

37. Hesselink AW, Weerts HJT, Berendsen HJA (2003) Alluvial architecture of the human-influenced river Rhine, The Netherlands. Sediment Geol 161:229-248. https://doi.org/10.1016/S0037-0738(03)00116-7

38. Heyvaert VMA, Walstra J (2016) The role of long-term human impact on avulsion and fan development. Earth Surf Process Landf 41:2137-2152. https://doi.org/10.1002/esp.4011

39. Hillebrand G, Frings RM. (2017) Von der Quelle zur Mündung: Die Sedimentbilanz des Rheins im Zeitraum 1991-2010. Bericht der KHR Report of the CHR, no II-22. Internationale Kommission für die Hydrologie des Rheingebietes/International Commission for the Hydrology of the Rhine Basin, Utrecht

40. Hoffmann T (2015) Sediment residence time and connectivity in nonequilibrium and transient geomorphic systems. Earth Sci Rev 150:609627. https://doi.org/10.1016/j.earscirev.2015.07.008 
41. Hoffmann T, Erkens G, Gerlach R, Klostermann J, Lang A (2009) Trends and controls of Holocene floodplain sedimentation in the Rhine catchment. CATENA 77:96-106. https://doi.org/10.1016/j.catena.2008.09.002

42. Hoffmann T, Thorndycraft VR, Brown AG, Coulthard TJ, Damnati B, Kale VS, Middelkoop H, Notebaert B, Walling DE (2010) Human impact on fluvial regimes and sediment flux during the Holocene: review and future research agenda. Glob Planet Change 72:87-98. https://doi.org/10.1016/j. gloplacha.2010.04.008

43. Ibisate A, Ollero A, Díaz E (2011) Influence of catchment processes on fluvial morphology and river habitats. Limnética 30:169-182

44. James LA, Marcus WA (2006) The human role in changing fluvial systems: retrospect, inventory and prospect. Geomorphology 79:152-171. https:// doi.org/10.1016/j.geomorph.2006.06.017

45. Klimek K, Latocha A (2007) Response of small mid-mountain rivers to human impact with particular reference to the last 200 years; Eastern Sudetes, Central Europe. Geomorphology 92:147-165. https://doi.org/10. 1016/j.geomorph.2006.06.046

46. Koenzen U (2005) Fluss- und Stromauen in Deutschland: Typologie und Leitbilder; Ergebnisse des F+E-Vorhabens "Typologie und Leitbildentwicklung für Flussauen in der Bundesrepublik Deutschland" des Bundesamtes für Naturschutz ; FKZ: 80382 100. Angewandte Landschaftsökologie, H. 65. BfN-Schr--Vertrieb im Landwirtschaftsverl., Münster

47. Kondolf GM (1997) PROFILE: hungry water: effects of dams and gravel mining on river channels. Environ Manage 21:533-551. https://doi.org/ 10.1007/s002679900048

48. Kondolf GM, Gao Y, Annandale GW, Morris GL, Jiang E, Zhang J, Cao Y, Carling P, Fu K, Guo Q, Hotchkiss R, Peteuil C, Sumi T, Wang H-W, Wang Z, Wei Z, Wu B, Wu C, Yang CT (2014) Sustainable sediment management in reservoirs and regulated rivers: experiences from five continents. Earth's Future 2:256-280. https://doi.org/10.1002/2013EF000184

49. Lang A, Bork H-R, Mäckel R, Preston N, Wunderlich J, Dikau R (2003) Changes in sediment flux and storage within a fluvial system: some examples from the Rhine catchment. Hydrol Process 17:3321-3334. https://doi.org/10.1002/hyp.1389

50. Larsen A, Bork H-R, Fuelling A, Fuchs M, Larsen JR (2013) The processes and timing of sediment delivery from headwaters to the trunk stream of a Central European mountain gully catchment. Geomorphology 201:215-226. https://doi.org/10.1016/j.geomorph.2013.06.022

51. Lehmkuhl F, Römer W (under review) Anthropogenic geomorphology-change of process dynamics and landscapes from an ecozonal perspective

52. Lehmkuhl F, Loibl D, Borchardt H (2012) Geomorphological map of the Wüstebach (Nationalpark Eifel, Germany) —an example of human impact on mid-European mountain areas. J Maps 6:520-530. https://doi.org/10. 4113/jom.2010.1118

53. Lehmkuhl F (2011) Die Entstehung des heutigen Naturraums und seine Nutzung. In: Kraus T, Pohle F (eds) Die natürlichen Grundlagen - von der Vorgeschichte bis zu den Karolingern, pp 87-129

54. Lewin J, Macklin MG, Johnstone E (2005) Interpreting alluvial archives: sedimentological factors in the British Holocene fluvial record. Quat Sci Rev 24:1873-1889. https://doi.org/10.1016/j.quascirev.2005.01.009

55. Maaß A-L, Esser V, Frings RM, Lehmkuhl F, Schüttrumpf H (2018) A decade of fluvial morphodynamics: relocation and restoration of the Inde River (North-Rhine Westphalia, Germany). Environ Sci Eur. https://doi.org/10. 1186/s12302-018-0170-0

56. Maaß A-L, Schüttrumpf H (2019) Reactivation of floodplains in river restorations: long-term implications on the mobility of floodplain sediment deposits. Water Resour Res 55:8178-8196. https://doi.org/10.1029/2019W R024983

57. Maaß A-L (2019) Looking back, looking forward: Human impacts on fluvial morphodynamics since the Industrial Revolution and the return to a natural morphological river state, Dissertation. https://doi.org/10.18154/ RWTH-2019-08256

58. Macklin MG, Lewin J, Jones AF (2014) Anthropogenic alluvium: an evidence-based meta-analysis for the UK Holocene. Anthropocene 6:26-38. https://doi.org/10.1016/jancene.2014.03.003

59. Middelkoop H, Erkens G, van der Perk M (2010) The Rhine delta-a record of sediment trapping over time scales from millennia to decades. J Soils Sediments 10:628-639. https://doi.org/10.1007/s11368-010-0237-z
60. Nilsson C, Reidy CA, Dynesius M, Revenga C (2005) Fragmentation and flow regulation of the World's Large River Systems. Science 308:405-408. https://doi.org/10.1126/science.1107887

61. Notebaert B, Verstraeten G (2010) Sensitivity of West and Central European river systems to environmental changes during the Holocene: a review. Earth Sci Rev 103:163-182. https://doi.org/10.1016/j.earscirev. 2010.09.009

62. Pasquale N, Perona P, Schneider P, Shrestha J, Wombacher A, Burlando P (2010) Modern comprehensive approach to monitor the morphodynamic evolution of restored river corridors. Hydrol Earth Syst Sci Discuss 7:8873-8912. https://doi.org/10.5194/hessd-7-8873-2010

63. Petts GE (2016) Complex response of river channel morphology subsequent to reservoir construction. Progress in Physical Geography 3:329-362. https://doi.org/10.1177/030913337900300302.

64. Patt H (2016) Fließgewässer- und Auenentwicklung: Grundlagen und Erfahrungen, 2nd edn. Springer Vieweg, Berlin

65. Protze J (2014) Eine "Mensch-gemachte Landschaft", Diachrone, geochemische und sedimentologische Untersuchungen an anthropogen beeinflussten Sedimenten und Böden der Niederrheinischen Lössbörde. Dissertation, RWTH Aachen University

66. Reiß S, Dreibrodt S, Lubos CCM, Bork H-R (2009) Land use history and historical soil erosion at Albersdorf (northern Germany) — ceased agricultural land use after the pre-historical period. CATENA 77:107-118. https:// doi.org/10.1016/j.catena.2008.11.001

67. Rommens T, Verstraeten G, Bogman P, Peeters I, Poesen J, Govers G, van Rompaey A, Lang A (2006) Holocene alluvial sediment storage in a small river catchment in the loess area of central Belgium. Geomorphology 77:187-201. https://doi.org/10.1016/j.geomorph.2006.01.028

68. Schmidt JC, Wilcock PR (2008) Metrics for assessing the downstream effects of dams. Water Resour Res 44:1757. https://doi.org/10.1029/ 2006WR005092

69. Schmidt-Wygasch C.M. (2011) Neue Untersuchungen zur holozänen Genese des Unterlauf der Inde. Chronostratigraphische Differenzierung der Auelehem unter besonderer Berücksichtigung der Montangeschichte der Voreifel. Dissertation, RWTH Aachen University

70. Schneider FK (1982) Untersuchungen über den Gehalt an Blei und anderen Schwermetallen in den Böden und Halden des Raumes Stolberg (Rheinland). In: Bundesanstalt für Geowissenschaften und Rohstoffe (ed) Geologisches Jahrbuch D 53. Schweizerbart, Stuttgart, pp 3-31

71. Schüttrumpf H, Niemann A (2016) Positionspapier "Living Rivers"zur Umsetzung der EG-Wasserrahmenrichtlinie in Wissenschaft und Praxis. Wasser und Abfall 18:43-44

72. Stanley DJ, Warne AG (1993) Nile Delta: Recent Geological Evolution and Human Impact. Science 260(5108):628-634. https://doi.org/10.1126/ science.260.5108.628

73. Starkel $L$ (2002) Change in the frequency of extreme events as the indicator of climatic change in the Holocene (in fluvial systems). Quat Int 91:25-32. https://doi.org/10.1016/S1040-6182(01)00099-4

74. Surian N, Rinaldi M (2003) Morphological response to river engineering and management in alluvial channels in Italy. Geomorphology 50:307-326. https://doi.org/10.1016/S0169-555X(02)00219-2

75. Syvitski JPM, Milliman JD (2007) Geology, geography, and humans battle for dominance over the delivery of fluvial sediment to the Coastal Ocean. J Geol 115:1-19. https://doi.org/10.1086/509246

76. Syvitski JPM, Vörösmarty CJ, Kettner AJ, Green P (2005) Impact of humans on the flux of terrestrial sediment to the global coastal ocean. Science 308:376-380. https://doi.org/10.1126/science.1109454

77. Tarolli P (2016) Humans and the Earth's surface. Earth Surf Process Landf 41:2301-2304. https://doi.org/10.1002/esp.4059

78. Török GT, Józsa J, Baranya S (2019) Validation of a novel, shear reynolds number based bed load transport calculation method for mixed sediments against field measurements. Water 11(10):2051. https://doi.org/10. 3390/w11102051

79. van Oorschot M (2017) Riparian vegetation interacting with river morphology: modelling long-term ecosystem responses to invasive species, climate change, dams and river restoration. Utrecht studies in earth sciences, vol 141. Universiteit Utrecht, Utrecht

80. Vandenberghe J, de Moor JJW, Spanjaard G (2012) Natural change and human impact in a present-day fluvial catchment: The Geul River, Southern Netherlands. Geomorphology 159-160:1-14. https://doi.org/ 10.1016/j.geomorph.2011.12.034 
81. Verstraeten G, Broothaerts N, van Loo M, Notebaert B, D'Haen K, Dusar B de Brue H (2017) Variability in fluvial geomorphic response to anthropogenic disturbance. Geomorphology 294:20-39. https://doi.org/10.1016/j. geomorph.2017.03.027

82. Vörösmarty C, Mclntyre P, Gessner M (2010) Global threats to human water security and river biodiversity. Nature 467:555-561. https://doi.org/ 10.1038/nature09440.

83. Vörösmarty CJ, Meybeck M, Fekete B, Sharma K, Green P, Syvitski JPM (2003) Anthropogenic sediment retention: major global impact from registered river impoundments. Glob Planet Change 39:169-190. https:// doi.org/10.1016/S0921-8181(03)00023-7

84. Walling DE (2006) Human impact on land-ocean sediment transfer by the world's rivers. Geomorphology 79:192-216. https://doi.org/10.1016/j. geomorph.2006.06.019

85. Walling DE (2016) The changing suspended sediment loads of the world's rivers and implications for land-ocean sediment fluxes. In: Schüttrumpf $H$ (ed) Offene Gewässer: Strahlwirkung, Fischaufstieg, Fischabstieg, Sedimente, Schadstoffe: 45. IWASA Internationales Wasserbau Symposium Aachen 2015. Shaker, Aachen

86. Walter RC, Merritts DJ (2008) Natural streams and the legacy of waterpowered mills. Science 319:299-304. https://doi.org/10.1126/science. 1151716

87. Water Research Institute (2019) Long-term morphological development of the danube in relation to the sediment balance, Interreg project, project-reference number DTP-1-1-195-2.1, http://www.interreg-danube. eu/approved-projects/danubesediment

88. WCD (2000) Dams and development: a new framework for decisionmaking: the report of the World Commission of Dams, London

89. Wohl E (2005) Compromised rivers: understanding historical human impacts on rivers in the context of restoration. E\&S. https://doi.org/10. 5751/ES-01339-100202
90. Wohl E, Lane SN, Wilcox AC (2015) The science and practice of river restoration. Water Resour Res 51:5974-5997. https://doi.org/10.1002/2014W R016874

91. Wolf S, Esser V, Schüttrumpf H, Lehmkuhl F (2021) Influence of 200 years of water resource management on a typical central European river. Does industrialization straighten a river? Environ Sci Eur 33:15. https://doi.org/ 10.1189/s12302-021-00460-8

92. Yamani (2011) The effect of human activities on river bank stability (case study). Am J Environ Sci 7:244-247. https://doi.org/10.3844/ajessp.2011. 244.247

93. Zhang M, Huang HQ, Carling PA (2017) Sedimentation of overbank floods in the confined complex channel-floodplain system of the Lower Yellow River, China. Hydrol Process 31:3472-3488. https://doi.org/10.1002/hyp. 11260

94. Zimmermann KP, Wendt KP, FrankT, Hilpert J (2009) Landscape archaeology in Central Europe. Proc Prehist Soc 75:1-53

95. Zolitschka B, Behre K-E, Schneider J (2003) Human and climatic impact on the environment as derived from colluvial, fluvial and lacustrine archives - examples from the Bronze Age to the Migration period, Germany. Quat Sci Rev 22:81-100. https://doi.org/10.1016/S0277-3791(02) 00182-8

\section{Publisher's Note}

Springer Nature remains neutral with regard to jurisdictional claims in published maps and institutional affiliations.

\section{Submit your manuscript to a SpringerOpen ${ }^{\circ}$ journal and benefit from:}

- Convenient online submission

- Rigorous peer review

- Open access: articles freely available online

- High visibility within the field

- Retaining the copyright to your article

Submit your next manuscript at $\boldsymbol{\nabla}$ springeropen.com 